JPSCR: Journal of Pharmaceutical Science and Clinical Research, 2021, 02, 203-215

DOI: $10.20961 /$ jpscr.v6i2.43256

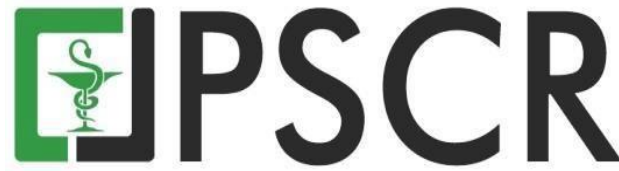

\title{
Pengaruh Media Kartu Tilik Terhadap Pengetahuan dan Perilaku Pengelolaan Obat Dagusibu di Jakarta Pusat Berdasarkan Home Pharmacy Care
}

\author{
Adin Hakim Kurniawan*, Yusmaniar dan Purnama Fajri \\ Prodi Farmasi, Poltekkes Kemenkes Jakarta II, Jl. Percetakan Negara no 23, Indonesia 10560 \\ *e-mail korespondensi: adin.hakim@poltekkesjkt2.ac.id \\ Received 26July 2020, Accepted 31 May 2021, Published 15 July 2021
}

\begin{abstract}
Abstrak: Penyimpanan dan pembuangan obat kurang tepat menjadi masalah pengelolaan obat yang berdampak negatif pada kesehatan masyarakat. Hubungan perilaku negatif pada pengelolaan obat dirumah tangga, lebih cenderung berisiko bagi pasien dengan riwayat penyakit degeneratif dan polifarmasi. Kepedulian tenaga farmasi terhadap pelayanan kefarmasian untuk pasien penyakit degeneratif, diwujudkan dalam kegiatan home pharmacy care. Edukasi kesehatan melalui pemberian aplikator media kartu tilik merupakan segala upaya yang direncanakan dengan cara membantu mengatasi pasien dalam penataan pengelolaan dagusibu obat dirumah tangga. Tujuan pada penelitian yaitu menganalisis Pengaruh Kartu Tilik terhadap Perilaku Pengelolaan Dagusibu Obat pada masyarakat di wilayah Jakarta Pusat berdasarkan Home Pharmacy Care. Jenis penelitian adalah observasional dengan sistem rancang penelitian crossectional. Teknik dalam pengambilan sampel Cluster random sampling. Analisis statistik menggunakan bivariat. Analisis inimenjelaskanadanya pengaruh yang signifikan media kartu tilik terhadap pengetahuan pengelolaan obat $(\mathrm{p}=0,024$; OR 2,526$)$; terhadap perilaku pengelolaan obat $(p=0,0310 R$ 2,865). Kesimpulan memiliki hubungan yang bermakna antara media kartu tilik terhadap pengetahuan dan perilaku pengelolaan Obat Dagusibu berdasarkan home pharmacy care.
\end{abstract}

Kata Kunci: Kartu tilik; Perilaku; Pengelolaan Dagusibu

Abstract. The influence of a house visit card on the behavior of dagusibu drug management based on home pharmacy care. Drug management is a potential public health problem due to the risk of improper storage and disposal of drugs. Negative behavior relationship in household drug management could provide a considerable risk, especially to the patient with a history of degenerative disease and closely related to polypharmacy. Pharmacist care in health services for sufferers of degenerative diseases is manifested inhome pharmacy care activities. Health education by giving a media card applicator all efforts planned to help patients manage dagusibu drugs in the household. The purpose of this study can analyze the Influence of a house visit card on drug management behavior in Central Jakarta. The sampling technique used by the author is cluster random sampling. Statistical analysis using bivariate with the statistical test used was the chi-square test. The bivariate analysis results showed a significant influence of media house visit cards on knowledge of drug management ( $\mathrm{p}=0.024$; OR 2.526); towards drug management attitudes $(\mathrm{p}=0.023$; OR 2.584). The conclusion has a significant relationship between media house visit cards on the behavior of Dagusibu Drug management based on home pharmacy care (p-value 0.031; OR value 2.865 ).

Keywords: House Visit Card; Behaviour; Dagusibu Management 


\section{Pendahuluan}

Pengelolaan obat ethical dan OTC di seluruh dunia, umumnya dapat digunakan sebagai indikasi sehari-hari dalam menangani penyakit akut atu kronis. (Wieczorkiewicz et al., 2013). Pembiayaan obat yang meningkat dan jumlah penggunaan obat yang tinggi di rumah tangga memiliki pengaruh perilaku sikap dan tindakan bagi pasien, lingkungan keluarga terutama orang tua lansia yang terdapat komorbid penyakit degenaratif dan total item obat meningkat banyak di rumahnya (Martins et al., 2017). Obat telah menjadi masalah kesehatan yang potensial dalam beberapa tahun terakhir karena risiko pembuangan dan simpan yang kurang tepat. Peraturan publik di berbagai negara kurang mengatur pembuangan obat, yang menjadikan dampak meluasnya limbah domestik dan alur pembuangan menjadi tidak teratur sehingga terjadinya polusi lingkungan (Rambhade et al., 2012).

Pelayanan kesehatan dapat diwujudkan secara optimal, untuk itu diperlukan suatu bentuk pharmaceutical care terhadap pasien dengan riwayat penyakit degeneratif. Wujud dariasuhan kefarmasian yang diberikan oleh tenaga farmasi dalam pelayanan kesehatan terhadap pasien degeneratif melalui asuhan kefarmasian rumah tangga (home pharmacy care) (MacKeigan \& Nissen, 2008).

Kegiatan home pharmacy care merupakan cara mendampingi pasien oleh tenaga kefarmasian ketika memberikan pelayanan asuhan kefarmasian di satu rumah tangga dengan memberikan informed consent kepada anggota keluarganya (American Society of HealthSystem Pharmacists, 2006). Edukasi kesehatan melalui pemberian aplikator media kartu tilik merupakan segala upaya yang direncanakan untuk membantu pasien dalam penataan pengelolaan dagusibu obat dirumah tangga. Apoteker dapat melakukan observasi melalui media kartu tilik sekaligus memberikan stiker labelisasi di kotak penyimpanan obat yang berisi edukasi cara melakukan pengelolaan dagusibu obat ini secara baik dan benar, sehingga masyarakat tidak sengaja maupun disengaja menyadari, mengetahui, namun dapat menjalankan anjuran kesehatan (DepKes RI, 2008).

Memberikan nilai edukasi pasien tentang penggunaan obat dengan riwayat penyakit degeneratif seperti jantung dan hipertensi, TBC, Asma dan lain-lain salah satu bentuk dari pelayanan asuhan kefarmasian di rumah tangga. Drug related problem timbul akibat rendahnya nilai edukasi pengetahuan mengenai pengelolaan dagusibu obat dari tindakan perilaku kesehatan (Ensing et al., 2018). Tindakan yang bukan dilandasi dengan nilai edukasi dan tindak kesadaran maka nilai perilaku akan menjadi negatif dan cendrung lama berproses, sedangkan sebaliknya pada nilai edukasi dan tindak kesadaran yang positif akan lebih lama bermanfaat (Notoatmodjo, 2007). 
Penelitian tentang perilaku pengelolaan Dagusibu Obat pernah dilakukan oleh beberapa peneliti, namun penelitian ini seringkali hanya melakukan edukasi dilapangan berupa simulasi penyuluhan tanpa dilakukan home to home dengan pengecekan langsung dengan media kartu tilik. Risiko pasien yang memiliki masalah berhubungan dengan obat biasanya pasien dengan kriteria tersebut, misalnya riwayat penyakit sebelumnya (komorbiditas), pasien lansia, lingkungan, karakteristik jenis obat, pengobatan yang kompleks, kebingungan, serta kurangnya edukasi pengetahuan dan keterampilan menggunakan obat (Ahmad, 2019).Cara untuk mengatasi hal tersebut diperlukan penelitian serupa tetapi dibutuhkan evaluasi dan pelaporan berupa kartu media tilik dengan mengambil keseluruhan populasi yang lebih luas, khususnya yang kami lakukan di wilayah Jakarta Pusat. Berdasarkan uraian tersebut diperlukan sebuah penelitian yang berhubungan dengan peran tenaga kefarmasian terutama Apoteker dalam menjalankan pelayanan kefarmasian di rumah dengan memberikan informasi dengan menggunakan aplikator kartu tilik obat dan stiker label. Permasalahan tersebut diharapkan dapat meningkatkan perilaku pengelolaan dagusibu obat khususnya masyarakat di wilayah Jakarta Pusat. Tujuan dari penelitian ini adalah memberikan kesadaran pengetahuan dan perilaku masyarakat melalui media kartu tilik obat di wilayah Jakarta Pusat berdasarkan

\section{Home Pharmacy.}

\section{Metode}

Jenis penelitian ini melalui pendekatan deskriptif kuantitatif dengan desain cohort prospective. Variabel independen berupa media kartu tilik, sedangkan variabel terikatnya adalah pengetahuan dan perilaku pengelolaan dagusibu obat.

Populasi terlibat dalam penelitian adalah masyarakat datang berobat ke puskesmas kecamatan yang berada di wilayah Jakarta Pusat. Jenis sampel pada penelitian yaitu cluster sampling. Perolehan sampel berasal dari dua kecamatan wilayah Johar Baru dan Cempaka Putih sebanyak 116 responden. Subjek uji dibagi menjadi dua kelompok perlakuan yaitu kelompok mendapatkan kartu tilik dan media kotak yang diberi dagusibu (Gambar 1) dan kelompok yang tidak mendapatkan kartu tilik tetapi hanya mendapatkan media kotak obat tanpa diberikan stiker dagusibu (kontrol).

Variabel bebas pada penelitian adalah kartu kunjungan dan stiker tempel dagusibu obat dengan metode Home Pharmacy Care. Poltekkes kemenkes Jakarta 2 merupakan institusi yang mengeluarkan ethical approved dengan nomor LB.02.01/I/KE/38/464/2019 KPEK-PKJ II.

Kriteria inklusi responden adalahantara lain : (1) bertempat tinggal di wilayah Johar Baru dan Cempaka Putih dan memiliki identitas KTP, (2) bersedia menjadi responden 
dibuktikan dengan lembar persetujuan dannaskah penjelasan, (3) riwayat pasien berobat dan memiliki komorbid penyakit bawaan atau degeneratif, (4) mendapatkan atau tidak mendapatkan peresepan obat dan (5) satu kepala keluarga dari tiap rumah. Kriteria eksklusi penelitian meliputi : (1) respondenyang menjalankan perawatan dirumah sakit, (2) bermasalah pada kondisi penglihatan dan (3) meninggal saat penelitian berlangsung. Prosedur pengambilan data menggunakan instrumen kuisioner yang didapat berdasarkan survey, meliputi : data riwayat responden, praktek responden dalam pengisian kartu tilik obat, kuisioner pengetahuandan perilaku pengelolaan dagusibu obat.

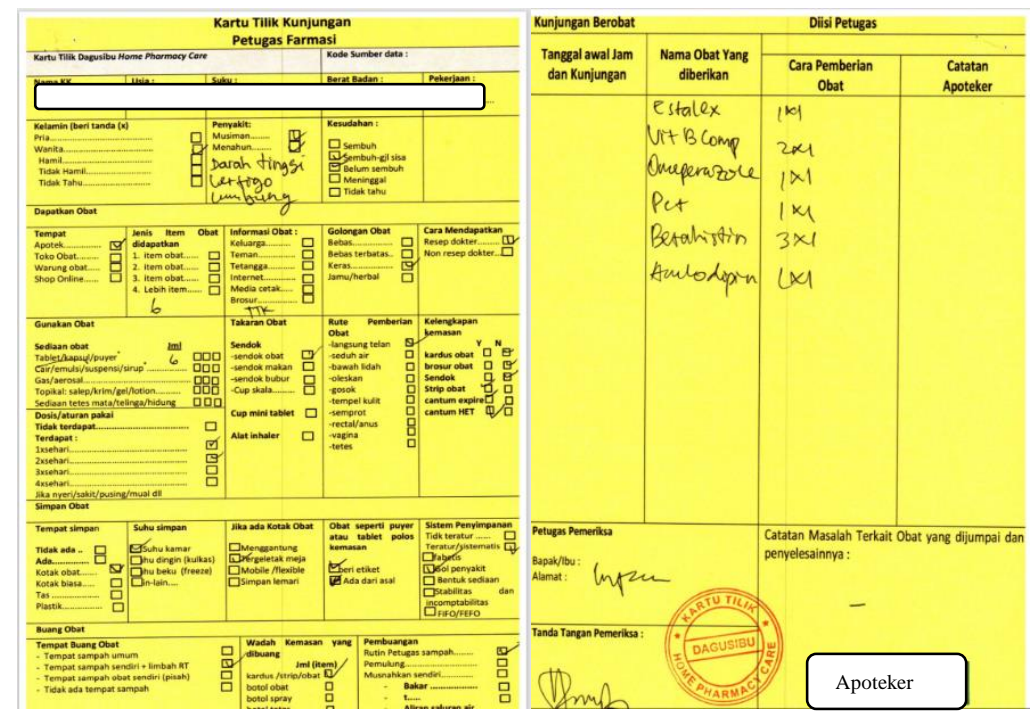

Gambar 1. Media kartu tilik dagusibu obat kecamatan Johar Baru dan Kecamatan Cempaka Putih.

Responden mendapatkan pertanyaan terkait pengetahuan dan perilaku pengelolaan obat di rumah tangga, sebelumnya peneliti memberikan penjelasan mengenai cara pengisian kartu tilik terhadap kelompok intervensi, yang meliputi : dapatkan, gunakan, simpan dan buang obat. Sedangkan pada kelompok kontrol hanya diberikan media kotak obat tanpa diberi stiker label dagusibu serta media kartu tilik dagusibu obat (Gambar 1). Pengamatan pada kedua kelompok dilakukan selama selama 2 bulan, kemudian peneliti melakukan kunjungan kembali untuk melakukan evaluasi.

Pengambilan data menggunakan data primer yang terdiri dari kuisioner terbuka dan kuisioner tertutupuntuk mengukur tingkat pengetahuan dan sikap responden dan pertanyaan terbuka tentang praktek cara pengisian kartu tilik dagusibu obat. Pada bagian kuisioner pengetahuan dan sikap atau persespsi mengenai pengelolaan dagusibu obat terdapat 15 item pernyataan yang dibagi menjadi 8 item favorable dan 7 item un favorabel. Tanggapan yang diperoleh dari responden yaitutanggapan bersifat "forced choice" dengan memilih "Ya" dan "Tidak". Proses penilaian skor dilakukan setelah reseponden mengisi kuisioner yang 
diberikan. Nilaipengetahuandikatakan baik jika jawaban benar $\geq 70 \%$ atau dapat menjawab benar $\geq 11$ item pernyataan. Pengetahuan kurang baik jika nilainya $<70 \%$ atau dapat menjawab benar $<11$ item pernyataan.

Pada pengukuran perilakudengan cara linkert. Tingkat perilaku dikatakan memberikan nilai positif apabila responden dapat menjawab pertanyaan di kuisioner pada nilai benar $\geq 70 \%$ atau menjawab benar dengan jumlah soal $\geq 11$ item pernyataan. Adapun sebaliknya, penilaian perilakunegatif dikatakan kurang baik apabila responden menjawab pernyataan pada kuisioner dengan benar $<70 \%$ atau menjawab benar soal pernyataan dengan jumlah soal $<11$ item pernyataan.

Pendidikan, jenis kelamin, riwayat pekerjaan terakhir, usia, pengetahuan, sikap, media tilik dan stiker serta perilaku pengelolaan dagusibu obat adalah variabel yang digunakan sebagai data karakteristik demografis responden.Analisa data statistik menggunakan univariat, bivariat dengan uji Chi-square. (Dahlan, 2014).

\section{Hasil dan Pembahasan}

\subsection{Karakteristik demografi responden}

Penelitian dilakukan di dua wilayah Puskesmas kecamatan yaitu kecamatan Johar Baru dan Kecamatan Cempaka putih. Sampel dalam penelitian ini dilakukan secara menyeluruh sesuai dengan perhitungan slovin sebanyak 116 orang. Yang dibagi menjadi 2 kelompok uji. Kelompok kontrol dilakukan oleh Puskesmas Kecamatan wilayah Cempaka Putih sebanyak 58 sampel yang memiliki kelompok sebanding dengan kelompok intervensi (puskesmas Kecamatan Johar Baru). Responden tidak ada yang menolak selama mengikuti penelitian, sehingga terdapat $100 \%$ sesuai dengan inklusi dan eksklusi.Faktor demografis yang mempengaruhi pengelolaan obat dirumah tangga antara lain faktor jenis kelamin, usia dan riwayat bekerja (Huang et al., 2019).

Data karakteristik (Tabel 1) menunjukkan bahwa proporsi distribusi jenis kelamin perempuan sebagian besar lebih banyak daripada laki-laki. Pada penelitian lain juga mengungkapkan terdapat perbedaanantara pengetahuan laki-laki dan perempuan,dimana perempuan lebih mudah berinteraksi dan peduli daripada laki-laki terutama di bidang sosial masyarakat (Puspasari et al, 2018).

Jumlah responden paling banyak berdasarkan usia responden yang mengikuti penelitian tersebut adalah pada usia produktif (18-64 tahun ), Penelitian lain yang dilakukan oleh (Savira et al., 2020), mengungkap kansalah satu faktor yang mungkin mempengaruhi pengetahuan praktik penyimpanan dan pembuangan obat dalam keluarga berdasarkan karakteristik usia responden yang paling banyak pada usia produktif kisaran 41-60 tahun dengan persentase 
sebanyak 47,80\%. Usia merupakan faktor yang berpengaruh besar dengan cara pandang, pemikiran dan penilaian terhadap pengetahuan seseorang (Notoatmodjo, 2007).

Tabel 1. Karakteristik demografi responden pada penggunaan media kartu tilik dagusibu obat berdasarkan Home Pharmacy Care. Keterangan: intervensi yang dilakukan menggunakan alat stimulator (kartu tilik) dan kontrol tanpa diberikan alat stimulator.

\begin{tabular}{|c|c|c|c|c|}
\hline \multirow{2}{*}{ Karakteristik Demografi } & \multicolumn{2}{|c|}{$\begin{array}{c}\text { Intervensi } \\
\text { (Johar Baru) }\end{array}$} & \multicolumn{2}{|c|}{$\begin{array}{c}\text { Kontrol } \\
\text { (Cempaka Putih) }\end{array}$} \\
\hline & $\begin{array}{c}\text { Frekuensi } \\
(\mathrm{N}=58)\end{array}$ & $\begin{array}{c}\text { Persentase } \\
(\%)\end{array}$ & $\begin{array}{l}\text { Frekuensi } \\
(\mathbf{N}=58)\end{array}$ & $\begin{array}{c}\text { Persentase } \\
(\%)\end{array}$ \\
\hline \multicolumn{5}{|l|}{ 1. Jenis Kelamin } \\
\hline Perempuan & 49 & 84,5 & 51 & 87,9 \\
\hline Laki-laki & 9 & 15,5 & 7 & 12,1 \\
\hline \multicolumn{5}{|l|}{ 2. Usia } \\
\hline $\begin{array}{l}\text { Produktif } \\
\text { (18-64 tahun) }\end{array}$ & 41 & 70,7 & 49 & 84,5 \\
\hline Non produktif ( $\geq 65$ tahun) & 17 & 29,3 & 9 & 15,5 \\
\hline \multicolumn{5}{|l|}{ 3. Jenis Pekerjaan } \\
\hline Ibu Rumah Tangga & 26 & 44,8 & 38 & 65,5 \\
\hline Pensiunan/ Pengangguran & 11 & 19,0 & 6 & 10,3 \\
\hline Pegawai swasta & 6 & 10,3 & 7 & 12,1 \\
\hline Pegawai Negeri & 8 & 13,8 & 3 & 5,2 \\
\hline Wiraswasta/berdagang/buruh & 7 & 12,1 & 3 & 5,2 \\
\hline Pelajar Mahasiswa & 0 & 0 & 1 & 1,7 \\
\hline
\end{tabular}

Pada karakteristik responden berdasarkan pekerjaan, proporsi jumlah ibu rumah tangga lebih banyak menderita penyakit degeneratif dibandingkan dengan responden kategori lain. Hal ini sangat berhubungan dengan faktor jenis kelamin bukan pada faktor berdasarkan riwayat pekerjan, berdasarkan penelitian lain, sebagian besar perempuan dengan pekerjaannya mampu menafkahi keluarga dalam beberapa kondisi diluar rumah sehingga memudahkan mereka memiliki riayayat penyakit yang berdampak pada pola yang hidup tidak sehat. Minimnya lahan pekerjaan, rendahnya penghasilan, mahalnya pendidikan anak sangat sering muncul manifestasi timbulnya gangguan emosi dan stress psikososial sehingga sering mengawali terjadinya penyakit degeneratif seperti hipertensi (Kristina et al., 2008)

\subsection{Karakteristik perilaku responden berdasarkan dapatkan gunakan simpan serta buang obat (Dagusibu)}

Responden di kedua puskesmas berperilaku ketika membeli obat golongan keras tanpa resep dokter di fasilitas kesehatan memiliki proporsi distribusi yang berbeda, responden puskesmas kecamatan Johar Baru memilih cara mendapatkan obat paling banyak dikunjungi adalah apotek (27,59\%), sedangkan responden puskesmas kecamatan Cempaka Putih memilih toko obat $(31,03 \%)$ (Tabel 2). Hal ini diperlukan pengawasan dan penertiban secara kontinyu terhadap distribusi obat keras sehingga masyarakat tidak dapat membeli obat tanpa resep 
dokter (Lenk \& Duttge, 2014). Memberikan obat golongan keras tanpa peresepan dokter merupakan salahsatu risiko kesalahan obat pada level individu dan masyarakat. Adapun kesalahan yang sering terjadi diantaranya ketidaktepatan diagnosis, kesalahan terapi pilihan, timbulnya efek yang mengakibatkan keparahan, kontraindikasi pada invidu, terdapatnya interaksi obat merugikan, peringatan dan pencegahan, gagal melaporkan pengobatan sendiri, minimalnya frekuensi dan ukuran dosis, penggunaan obat terlalu lama, risiko adiksi, dan penyalahgunaan obat (Rokhman, 2017).

Tabel 2. Karakteristik perilaku responden berdasarkan dapatkan, gunakan, simpan serta buang obat (dagusibu).

\begin{tabular}{|c|c|c|c|c|}
\hline \multirow{2}{*}{$\begin{array}{c}\text { Variabel Karakteristik } \\
\text { Perilaku }\end{array}$} & \multicolumn{2}{|c|}{$\begin{array}{c}\text { Intervensi } \\
\text { (Johar Baru) }\end{array}$} & \multicolumn{2}{|c|}{$\begin{array}{c}\text { Kontrol } \\
\text { (Cempaka Putih) }\end{array}$} \\
\hline & $\begin{array}{l}\text { Frekuensi } \\
(\mathrm{N}=58)\end{array}$ & $\begin{array}{c}\text { Persentase } \\
(\%)\end{array}$ & $\begin{array}{l}\text { Frekuensi } \\
(\mathbf{N}=58)\end{array}$ & $\begin{array}{l}\text { Persentase } \\
(\%)\end{array}$ \\
\hline \multicolumn{5}{|l|}{$\begin{array}{l}\text { 1.Cara Mendapatkan obatgolongan } \\
\text { keras tanpa resep dokter fasilitas } \\
\text { kesehatan }\end{array}$} \\
\hline a Apotek & 16 & 27,59 & 12 & 20,69 \\
\hline b Toko Obat & 9 & 15,52 & 18 & 31,03 \\
\hline c Fasilitas Rumah Sakit & 13 & 22,41 & 9 & 15,52 \\
\hline d Warung obat $(16,22 \%)$, & 1 & 1,72 & 8 & 13,79 \\
\hline e Klinik dll & 14 & 24,14 & 7 & 12,07 \\
\hline f Faskes Puskesmas & 5 & 8,62 & 4 & 6,90 \\
\hline \multicolumn{5}{|l|}{$\begin{array}{l}\text { 2. Cara menggunakan Obat yang } \\
\text { diperhatikan antara lain : }\end{array}$} \\
\hline $\begin{array}{l}\text { a Aturan pakai dan cara penggunaan } \\
\text { BSO }\end{array}$ & 18 & 31,03 & 20 & 34,48 \\
\hline b Batas kadaluarsa/expire date & 20 & 34,48 & 18 & 31,03 \\
\hline c Indikasi/Khasiat & 8 & 13,79 & 7 & 12,07 \\
\hline d Nama Obat & 4 & 6,90 & 3 & 5,17 \\
\hline e Brosur/label kemasan obat & 4 & 6,90 & 4 & 6,90 \\
\hline f Efek samping obat & 2 & 3,45 & 2 & 3,45 \\
\hline g Kemasan Obat & 1 & 1,72 & 2 & 3,45 \\
\hline h Nomor izin edar/registrasi & 1 & 1,72 & 2 & 3,45 \\
\hline \multicolumn{5}{|l|}{ 3.Cara Penyimpanan Obat } \\
\hline a Kotak penyimpanan obat khusus & 33 & 56,90 & 24 & 41,38 \\
\hline b Di lemari es & 8 & 13,79 & 30 & 51,72 \\
\hline $\begin{array}{l}\text { c Diatas meja /lemari (tanpa kotak } \\
\text { obat) }\end{array}$ & 17 & 29,31 & 4 & 6,90 \\
\hline \multicolumn{5}{|l|}{ 4. Cara Mermbuang Obat } \\
\hline a Dibuang langsung keadaan utuh & 15 & 25,86 & 28 & 48,28 \\
\hline b Dibuang dikloset/kamar mandi & 8 & 13,79 & 3 & 5,17 \\
\hline c Menghilangkan label obat & 2 & 3,45 & 2 & 3,45 \\
\hline $\begin{array}{l}\text { d Dihancurkan dicampur/ditimbun di } \\
\text { tanah }\end{array}$ & 33 & 56,90 & 25 & 43,10 \\
\hline
\end{tabular}

Perilaku cara menggunakan obat pada kedua kelompok puskesmas baik kecamatan Johar Baru maupun Cempaka putih memiliki proporsional distribusi yang sebanding, hal ini 
menunjukan bahwa responden ketika ingin menggunakan obat hal yang perlu diperhatikan paling banyak yaitu tentang aturan pakai dan cara menggunakan bentuk sediaan obat tersebut, hal tersebut dapat terlihat antara puskemas kecamatan Johar Baru (31,03\%) dan kecamatan Cempaka Puth (34,48\%). Informasi aturan dosis obat merupakan faktor yang dapat mempengaruhi nilai keberhasilan pengobatan. Informasi cara aturan pakai obat dapat dijelaskan kepada responden dengan kondisi melakukan dispensing obat sehingga dapat mempengaruhi pasien dalam menggunakan obat. Pemberian informasi cara pemakaian obat yang kurang jelas merupakan penyebab kesalahan pengobatan yang sering terjadi, dan sebaiknya dapat dihindari supaya tidak menimbulkan masalah dalam terapi pengobatan (Dewi \& Farida, 2018).

Proporsi perilaku cara menyimpan obat, kedua puskemas memiliki persentase yang berbeda, Puskesmas kecamatan Johar Baru memiliki cara penyimpanan obat khusus dikotak obat sebesar 56,90\%, sedangkan perilaku menyimpan obat di puskesmas Kecamatan Cempaka putih lebih banyak menyimpan lemari es sebesar 51,72\%. sehingga karakteristik perilaku kedua kelompok tersebut memiliki karakateristik tindakan yang berbeda. Seluruh jenis obat dilakukan penyimpanan yang kering, sejuk serta terlindung dari kondisi lembab dan penyinaran sehinggga dapat memperlambat penguraian. Obat lebih baik disimpan pada tempattidak mudah dijangkau oleh anak-anak (Flynn et al., 2019). Jenis sediaan obat tertentu dapat tersimpan di kulkas dan pada bungkus kemasan wajib tercantumkan. Bentuk dan jenis obat khusus disimpan pada lemari es adalah insulin. Tidak dianjurkan menyimpan obat sediaan tablet, kapsul, puyer serta sirup kebagian freezer yang terdapat didalam lemari es. Hal ini justru akan merusak zat aktif obat, begitu pula pada penyimpanan obat dalam mobil pada jangka waktu yang lama (Kheir et al., 2011).

Perilaku cara membuang obat anatara kedua puskesmas memiliki proporsional distribusi yang berbeda (Tabel 2) menunjukan tindakan perilaku responden puskesmas kecamatan Johar Baru terhadap cara membuang obat paling banyak dilakukan responden dengan cara menghancurkan obat terlebih dahulu kemudian dicampur dengan tanah/ditimbun $(56,90 \%)$ sedangkan tindakan perilaku membuang sampah berbanding terbalik pada responden dari Puskesmas Kecamatan Cempaka Putih yang menginginkan pembuangan obat dilakukan dalam keadaan utuh sebesar 48,28\%. Hal ini sejalan dengan penelitian yang dilakukan Aeshah AlAzmi, et al (2017) yang mengungkapkan bahwa hampir $73 \%$ dari responden membuang obat-obatan sisa, kadaluwarsa, tidak diinginkan, atau tidak digunakan dengan membuangnya di tempat sampah atau sampah. Sementara responden lainnya sekitar 50\% percaya bahwa 
memberikan obat-obatan sisa kepada keluarga, teman, atau pusat amal adalah metode terbaik dalam hal pembuangan obat (AlAzmi et al., 2017).

Pembuangan obat yang tidak tepat dapat membahayakan kalangan anak-anak, hewan, maupun lingkungan, oleh sebab itu selayaknya diselenggarakan program kesadaran kesehatan masyarakat untuk pembuangan obat-obatan yang kadaluwarsa, obat yang tidak diinginkan, atau tidak terpakai dengan aman dan layak. Jika apoteker memberikan informasi tentang pembuangan obat selama konseling, pasien akan mengembangkan praktik pembuangan yang positif. Selain itu, memberikan informasi pembuangan dengan setiap label obat yang dikeluarkan dapat memainkan peran penting dalam menyelesaikan masalah ini. Metode lain yang disarankan adalah mengatur kampanye kolaboratif, nasional, dan penyadaran memanfaatkan media sosial (Ayele \& Mamu, 2018).

\subsection{Perbedaan pengetahuan pengelolaan Dagusibu obat antara kelompok kontrol dan intervensi}

Pengetahuan merupakan unsur domain yang sangat penting pada tindakan atau perilaku seseorang. Tingkat pendidikan dan pembelajaran salah satu unsur yang utama yang mempengaruhi pengetahuan itu sendiri. Pembelajaran dimaksudkan untuk memberikan nilai pengetahuan khususnya cara pengisian kartu tilik dagusibu yang baik dan benar. Pada Tabel 3statistik analisa Chi-Square terdapat hasil bahwa nilai $\mathrm{p}=0,024<0,005$, menunjukan terdapat hubungan signifikan kartu tilik terhadap pengetahuan pengelolaan Dagusibu. Hal ini terlihat nilai $p$-value pada Tabel 3.

Tabel 3. Perbedaan pengetahuan pengelolaan dagusibu antara kelompok kontrol dan intervensi. Keterangan: intervensi yang diberikan kartu tilik dan kontrol tanpa diberikan media kartu tilik.

\begin{tabular}{|c|c|c|c|c|c|c|}
\hline \multirow{2}{*}{\multicolumn{2}{|c|}{ Variabel Responden }} & \multicolumn{2}{|c|}{$\begin{array}{c}\text { Pengetahuan } \\
\text { pembelajaran kartu tilik } \\
\text { Dagusibu }\end{array}$} & \multirow[t]{2}{*}{ p - value } & \multirow[t]{2}{*}{$\begin{array}{l}\text { Odd ratio } \\
\quad(\text { OR })\end{array}$} & \multirow[t]{2}{*}{$95 \% \mathrm{CI}$} \\
\hline & & Baik & Kurang baik & & & \\
\hline \multirow{2}{*}{ Kelompok } & Kontrol & $\begin{array}{c}19 \\
(37,3 \%) \\
\end{array}$ & $\begin{array}{c}39 \\
(60,0 \%) \\
\end{array}$ & \multirow{2}{*}{0,024} & \multirow{2}{*}{2,526} & \multirow{2}{*}{$\begin{array}{c}1,269- \\
5,861\end{array}$} \\
\hline & Intervensi & $\begin{array}{c}32 \\
(62,70)\end{array}$ & $\begin{array}{c}26 \\
(40,0 \%)\end{array}$ & & & \\
\hline
\end{tabular}

Hasil penelitian didapatkan bahwa kelompok intervensi yang mendapatkan pembelajaran kartu tilik memiliki nilai pengetahuan yang lebih baik (62,70\%) jika dibandingkan pada kelompok kontrol (yang tidak mendapatkan pembelajaran pelatihan aplikator kartu tilik dan stiker label) sebanyak 37,30\% (Tabel 3). Penelitian tersebut dapat dikatakan sejalan dengan penelitian Nursalam (2010), menyatakan bahwa adanya nilai perbedaan yang signifikan antara cara pengisian kartu KMS terhadap nilai pengetahuan 
seseorang dengan nilai $p$-value = 0,01 (Nursalam et al., 2010). Menurut Notoatmodjo (2007) pengetahuan, sikap perilaku serta tindakan seseorang dapat meningkat apabila dilakukan dengan cara pelatihan. Dalam rangka mencapai tujuan pendidikan, kegiatan pelatihan sangat berhubungan erat terhadap proses belajar mengajar (Notoatmodjo, 2007). Kelompok intervensi merupakan sebagian dari kelompok prolanis belum pernah diberikan edukasi dan alat aplikator media kartu tilik dagusibu obat di rumah, sehingga peneliti sangat tertarik dengan cara memicu responden untuk menggunakan alat aplikator kartu tilik dengan tujuan memberikan perilaku posiitif dalam pengelolaan dagusibu obat dirumah secara kontinyu, baik dan benar. Nilai OR menjelaskan bahwa responden yang mendapatkan intervensi kartu tilik terhadap pengetahuan pengelolaan dagusibu obat secara benar akan memiliki perilaku yang baik pula sebesar 2,526 kali jika dibandingkan dengan responden pada kelompok normal yang tidak mendapat media kartu tilik.

\subsection{Hubungan antara aplikator kartu tilik terhadap perilaku pengelolaan Dagusibu}

Jumlah dan persentase responden pada kelompok intervensi memiliki perilaku positif pengelolaan dagusibu obat dengan home pharmacy care sebanyak 69,0\%. Analisa statistik uji Chi-Square mendapatkan nilai $p=0,000<0,050$, hal ini menunjukan hubungan yang signifikan antara aplikator kartu tilik terhadap perilaku pengelolaan dagusibu pada nilai $p=0,031$. Nilai OR menunjukan bahwa responden menggunakan aplikator kartu tilik memiliki pemahaman perilaku yang positif dalam pengelolaan dapatkan, gunakan, simpan serta membuang obat sebesar 2,865 kali jika dibandingkan dengan kelompok yang tanpa menggunakan media kartu tilik. Hal ini terlihat nilai $p$-value yang terdapat pada Tabel 4.

Tabel 4. Hubungan antara aplikator kartu tilik terhadap perilaku pengelolaan dagusibu. Keterangan: intervensi yang diberikan kartu tilik dan sticker label serta kontrol tanpa diberikan media kartu tilik dan sticker label.

\begin{tabular}{|c|c|c|c|c|c|c|}
\hline \multirow{2}{*}{\multicolumn{2}{|c|}{ Variabel Responden }} & \multicolumn{2}{|c|}{$\begin{array}{c}\text { Perilaku Pengelolaan } \\
\text { Dagusibu Obat }\end{array}$} & \multirow{2}{*}{ p - value } & \multirow{2}{*}{$\begin{array}{l}\text { Odd ratio } \\
\quad(\mathrm{OR})\end{array}$} & \multirow{2}{*}{$95 \% \mathrm{CI}$} \\
\hline & & Baik & $\begin{array}{c}\text { Kurang } \\
\text { baik }\end{array}$ & & & \\
\hline \multirow{2}{*}{ Kelompok } & Kontrol & $\begin{array}{c}9 \\
(31,0 \%)\end{array}$ & $\begin{array}{c}49 \\
(56,3 \%)\end{array}$ & \multirow{2}{*}{0,031} & \multirow{2}{*}{2,865} & \multirow{2}{*}{$\begin{array}{c}1,394- \\
6,746\end{array}$} \\
\hline & Intervensi & $\begin{array}{c}20 \\
(69,0)\end{array}$ & $\begin{array}{c}38 \\
(43,70 \%)\end{array}$ & & & \\
\hline
\end{tabular}

Responden yang terdapat pada kelompok kontrol termasuk dalam kategori perilaku negatif dalam pengelolaan obat di rumah tangga. Adapun yang menyebabkan hal tersebut karena responden tidak mendapatkan intervensi kejelasan informasi tentangbagaimana cara mengisi kartu tilik dagusibu obat sehingga nilai kelompok kontrol memiliki signifikasi lebih besar dari standar. Hal ini sejalan dengan ungkapan Notoatmodjo (2012) mengatakan bahwa 
tindakan (over behavior) belum tentu terwujud secara otomatis pada sikap perilaku seseorang, fasilitas dan faktor dukungan (support) merupakan salah satu faktor pendukung atau situasi yang kondusif dari bentuk perbuatan yang nyata (Notoatmodjo, 2012).

Perilaku meliputi persepsi, respon pemimpin, mekanisme dan adopsi. Adopsi bagian dari perilaku yang perlu dijalankan setelah menjalankan fase ke 4. Adopsi merupakan suatu praktek yang sudah berkembang dengan baik. Tindakan merupakan ranah perilaku setelah responden mendapatkan edukasi dan nilai sikap, dimana responden mendapatkan rangsangan objek, kemudian terevaluasi tentang apa yang didapat dan tersikapi (Prihapsara \& Velayanti, 2017). Media kartu tilik merupakan alat stimulator yang bertujuan memberikan penilaian yang tentunya perlu pengetahuan dan penyikapan apalagi responden telah diberikan bekal pelatihan sebelumnya dan aktif dalam kegiatan acara yang diisi oleh prolanis terutama pengelolaan dagusibu obat di rumah tangga. Tindakan mengelola obat dagusibu dengan benar akan menciptakan pengetahuan yang baik dan perilaku positif di lingkungan rumah tangga.

\section{Kesimpulan}

Hasil penelitian penggunaan aplikator kartu tilik dapat memiliki hubungan yang bermakna terhadap pengetahuan ( $p$-value 0,024; nilai OR 2,526; 95\% CI:1,269-5,861) dan perilaku pengelolaan obat rumah tangga bersifat positif ( $p$-value 0,031 ; nilai OR 2,865; $95 \%$ CI:1,394-6,746).

\section{Ucapan Terimakasih}

Terima kasih kami sampaikan kepada Badan PPSDMKes dan Poltekkes Kemenkes Jakarta 2 atas pendanaan penelitian melalui skema penelitian pemula tahun 2020 dan Puskesmas Kecamtan Jakarta Pusat atas kesediaan menjadi fasilitas penelitian.

\section{Deklarasi Konflik Kepentingan}

Semua penulis tidak ada konflik kepentingan terhadap naskah penelitian ini.

\section{Daftar Pustaka}

Ahmad, A. (2019). Home Pharmacy Care: Solusi Keberhasilan Terapi di Rumah. Farmasetika.Com (Online), 3(5), 70. https://doi.org/10.24198/farmasetika.v3i5.21634

AlAzmi, A., AlHamdan, H., Abualezz, R., Bahadig, F., Abonofal, N., and Osman, M. (2017). Patients' Knowledge and Attitude toward the Disposal of Medications. Journal of Pharmaceutics, 2017(2010), 1-9. https://doi.org/10.1155/2017/8516741

American Society of Health-System Pharmacists. (2006). Best Practices for Hospital and Health-System

Pharmacy. Https://Openlibrary.Org/Books/OL8816144M/Best_Practices_for_Hospital_and_Health -System_Pharmacy.

Ayele, Y., and Mamu, M. (2018). Assessment of knowledge, attitude and practice towards disposal of unused and expired pharmaceuticals among community in Harar city, Eastern Ethiopia. Journal of Pharmaceutical Policy and Practice, 11(1). https://doi.org/10.1186/s40545-018-0155-9

Dahlan, M. S. (2014). Statistik Untuk Kedokteran Dan Kesehatan Deskriptif, Bivariat dan 
Multivariat. Dilengkapi Alikasi Menggunakan SPSS. 6th ed. Jatinagor: Alqaprint; 2014. In Salemba Medika.

DepKes RI, D. B. F. K. andK. (2008). Pedoman Pelayanan Kefarmasian di Rumah (Home Pharmacy Care). 1-37. https://doi.org/10.1017/CBO9781107415324.004

Dewi, M. A. C., andFarida, Y. (2018). Tingkat Pengetahuan Pasien Rawat Jalan Tentang Penggunaan Antibiotika di Puskesmas Wilayah Karanganyar. JPSCR: Journal of Pharmaceutical Science and Clinical Research, 3(1), 27. https://doi.org/10.20961/jpscr.v3i1.15102

Ensing, H. T., Vervloet, M., van Dooren, A. A., Bouvy, M. L., andKoster, E. S. (2018). Patient-pharmacist communication during a post-discharge pharmacist home visit. International Journal of Clinical Pharmacy. https://doi.org/10.1007/s11096-018-0639-3

Flynn, A. D., Scheuerle, R. L., Galgon, G., Gerrard, S. E., andNetshandama, V. O. (2019). An assessment of infant medication administration and storage practices in selected communities in the Vhembe District of Limpopo Province, South Africa. Health SA Gesondheid. https://doi.org/10.4102/hsag.v24i0.1075

Huang, Y., Wang, L., Zhong, C., andHuang, S. (2019). Factors influencing the attention to home storage of medicines in China. BMC Public Health, 19(1), 833. https://doi.org/10.1186/s12889-019-7167-5

Kheir, N., El Hajj, M. S., Wilbur, K., Kaissi, R. M. L., andYousif, A. (2011). An exploratory study on medications in Qatar homes. Drug, Healthcare and Patient Safety. https://doi.org/10.2147/dhps.s25372

Kristina, S.A., Prabandari, Y.S., andSudjaswadi, R. (2008). Perilaku pengobatan sendiri yang rasional pada masyarakat Kecamatan Depok dan Cangkringan Kabupaten Sleman. Majalah Farmasi Indonesia, 19(1), 32-40.

Lenk, C., andDuttge, G. (2014). Ethical and legal framework and regulation for off-label use: European perspective. In Therapeutics and Clinical Risk Management. https://doi.org/10.2147/TCRM.S40232

MacKeigan, L. D., andNissen, L. M. (2008). Clinical pharmacy services in the home. In Disease Management and Health Outcomes. https://doi.org/10.2165/00115677200816040-00004

Martins, R. R., Farias, A. D., Oliveira, Y. M. da C., Diniz, R. D. S., andOliveira, A. G. (2017). Prevalence and risk factors of inadequate medicine home storage: a communitybased study. Revista de Saúde Pública, 51, 95. https://doi.org/10.11606/S15188787.2017051000053

Notoatmodjo, S. (2007). Promosi Kesehatan dan Ilmu Perilaku. In Rineka Cipta.

Notoatmodjo, Soekidjo. (2012). Promosi Kesehatan dan Perilaku Kesehatan (edisi revisi 2012). In Jakarta: rineka cipta.

Notoatmodjo, S. (2010). Konsep perilaku kesehatan. Promosi Kesehatan, Teori Dan Aplikasi.

Nursalam, Agustina, D., andAlit, N. K. (2010). Training Pengisian Kartu Menuju Sehat (KMS) Merubah Perilaku Kader Posyandu Balita. Jurnal Ners.

Prihapsara, F., andVelayanti, dan R. (2017). Pengaruh Sikap Dan Norma Subyektif Terhadap Niat Beli Personal sebagai Konsumen Potensial Produk Obat Kumur. Journal of Pharmaceutical Science and Clinical Research,2(1), 6-16.

Puspasari, H. et. a. (2018). Tingkat Pengetahuan Tentang "DAGUSIBU”Obat Antibiotik Pada Masyarakat Desa Sungai Awan Kiri Kecamatan Muara Pawan Kabupaten Ketapang Tahun 2017. Medical Sains, 3(1), 11-18.

Rambhade, S., Chakarborty, A., Shrivastava, A., Patil, U. K., andRambhade, A. (2012). A survey on polypharmacy and use of inappropriate medications. In Toxicology International. https://doi.org/10.4103/0971-6580.94506

Rokhman, M. R., Widiastuti, M., Suwarni, S., Fatmawati, R. F., Munawaroh, N. M., and Pramesti, Y. A. Dispensing Prescription Medicines without a Prescription in 
Pharmacy. JURNAL MANAJEMEN DAN PELAYANAN FARMASI (Journal of Management and Pharmacy Practice), 7(3), 115-124.

Savira, M., Ramadhani, F. A., Nadhirah, U., Lailis, S. R., Ramadhan, E. G., Febriani, K., Patamani, M. Y., Savitri, D. R., Awang, M. R., Hapsari, M. W., Rohmah, N. N., Ghifari, A. S., Majid, M. D. A., Duka, F. G., and Nugraheni, G. (2020). PRAKTIK PENYIMPANAN DAN PEMBUANGAN OBAT DALAM KELUARGA. Jurnal Farmasi Komunitas, 7(2), 38. https://doi.org/10.20473/jfk.v7i2.21804

Wieczorkiewicz, S. M., Kassamali, Z., and Danziger, L. H. (2013). Behind Closed Doors: Medication Storage and Disposal in the Home. Annals of Pharmacotherapy. https://doi.org/10.1345/aph.1r706

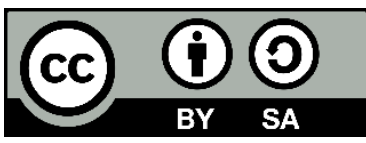

(C) 2021 by the authors. Submitted for possible open access publication under the terms and conditions of the Creative Commons Attribution-ShareAlike 4.0 International (CC BY-SA 4.0) license (https://creativecommons.org/licenses/by-sa/4.0/). 